\title{
Study on the Relationship between Rural Financial Services and Farmers' Income in Heilongjiang Province
}

\author{
Fengge Yao \\ Institute of Business \& Economic Research \\ Harbin University of Commerce \\ Harbin, China
}

\author{
Fuxin Li \\ Finance College \\ Harbin University of Commerce \\ Harbin, China \\ 1915461857@qq.com
}

\begin{abstract}
Based on the time series data of the 1999-2014 in Heilongjiang province, this paper uses the principal component analysis method to reduce the economic index of the rural financial services and calculates the value of rural financial service level in Heilongjiang province in the past years by using weight reduction index weight. With the aim to study the relationship between rural financial services and farmers' income, we established the VAR model. The results show that there is a long-term equilibrium between rural financial service level and peasant income in Heilongjiang province. The rural financial service level has a significant positive effect on the income of farmers in Heilongjiang province.
\end{abstract}

Keywords-Rural financial services; Farmers' income; The VAR model; The principal component analysis.

\section{INTRODUCTION}

Rural economy is an important part of the national economy, the past decade; the proportion of the first industry in Heilongjiang Province has been stable in more than $10 \%$. Farmers' income has always been a problem that can not be ignored, because increasing the income of farmers is not only the key to solve the "three rural", but also the ultimate goal of rural economic development. The improvement of rural financial service level is of great help to promote the increase of farmers' income, the development of modern agriculture and the stabilization of the overall situation of the rural areas. It is also conducive to the improvement of the rural financial environment and the sustainable development of the whole national economy [1].

The study of rural financial services dates to the late 19th and early 20th centuries. British scholar Potter first described the situation of British rural financial organizations; "the Cooperative Movement in Great Britain" article has become the basis for future generations of research. Followed by the American economist Patrick in 1966 pointed out the supply of guided and demand to follow the two types of financial development model [2].

Subsequently, scholars from various countries to study the rural financial services from different angles. The research has different degrees of innovation and development. The twentieth

\footnotetext{
This work is supported by the National Social Science Fund Project:

"Research on Rural Financial Service Innovation and Risk Control in the Context of Structural Reform of Supply Side.” The project number is 17BJY119.
}

century became the climax of the study. Including American economists represented by Mark Drabenstott (2007) and Alan D Barkema (2007), pointed out from the perspective of development that the reform of rural financial services organizations should be accelerated for the orderly implementation of the Financial Services Modernization Act (MA). Ben Young Tremblay (2009) and Daniel Coto (2009) represented the Canadian economists through a case study that rural credit cooperatives in the rural financial institutions in the process of capital innovation in the best choice.

Domestic scholars' research on rural financial services started late, but developed quickly. Especially in recent years, there have been abundant research results in China. Mainly related to rural financial institutions, service innovation and system innovation.

On the one hand, domestic scholars generally believe that China's rural financial services development is lagging [3-5]. Wang Heng (2014) based on the SCP paradigm and taking Shandong Province as the object of study, its rural financial service system and efficiency were measured and evaluated, the results show that rural financial services innovation in Shandong Province has a certain result and experience, but compared with urban financial services, there is still a big gap.

On the other hand, some scholars have analyzed the specific performance of rural financial services, trying to find out the reasons restricting the development of rural financial services in China[6].Xie Li-chen (2008) through the study of rural financial services in western China found that the reasons for the lack of rural financial services mainly in the following three aspects: First, the real economy profitability is weak, can't promote the effective allocation of financial resources; Second, fiscal support is inadequate, affecting the efficient and orderly operation of rural finance; Third, the rural financial system needs and supply there is a contradiction.

This paper breaks through the research framework of traditional financial development and peasant income, quantitatively discusses the relationship between rural financial service and farmers' income. Combined with the actual situation of rural financial services and farmers' income in Heilongjiang Province, through the empirical research on the statistical data, we can get the interactive relationship between 
the rural financial services and the farmers 'income. Through this study, it is of great practical significance to better serve the "three rural" and promote the growth of farmers' income in Heilongjiang Province. At the same time for the rural areas of the rapid development of financial fields and related areas of further reform and development to provide theoretical basis and data support.

\section{INDICATOR SELECTION AND DATA SOURCES}

\section{A. Indicator Selection}

This paper uses the relevant aspects of financial service infrastructure construction (the number of business outlets and service personnel), the level of deposit and loan, the situation of agricultural insurance services and the accessibility of financial services to reflect the status of financial services. Select per capita net income of rural residents as an indicator of the income of farmers. See Table I for details.

TABLE I. VARIABLE DEFINITIONS TABLE

\begin{tabular}{|c|c|c|}
\hline The variable name & variable indicates & the specific indicator \\
\hline $\begin{array}{c}\text { Bank organization } \\
\text { network }\end{array}$ & JG & $\begin{array}{l}\text { One thousand people } \\
\text { have bank outlets for } \\
\text { rural areas }\end{array}$ \\
\hline $\begin{array}{c}\text { The bank service } \\
\text { personnel }\end{array}$ & $\mathrm{CY}$ & $\begin{array}{c}\text { one thousand people } \\
\text { have bank service staff } \\
\text { number for rural areas }\end{array}$ \\
\hline $\begin{array}{c}\text { Deposits Business } \\
\text { Services }\end{array}$ & $\mathrm{CX}$ & $\begin{array}{l}\text { Per Capita Savings of } \\
\text { Rural Residents }\end{array}$ \\
\hline Loan business services & DK & $\begin{array}{c}\text { rural residents per capita } \\
\text { amount of agricultural } \\
\text { loans }\end{array}$ \\
\hline \multirow[t]{2}{*}{$\begin{array}{l}\text { Insurance Business } \\
\text { Service }\end{array}$} & $\mathrm{BF}$ & $\begin{array}{c}\text { Insurance Company } \\
\text { Agricultural Insurance } \\
\text { Premium Income (per } \\
\text { capita) }\end{array}$ \\
\hline & PK & $\begin{array}{c}\text { insurance company } \\
\text { agricultural insurance } \\
\text { claims and payment (per } \\
\text { capita) }\end{array}$ \\
\hline $\begin{array}{c}\text { Policy Financial } \\
\text { Services }\end{array}$ & $\mathrm{CZ}$ & $\begin{array}{c}\text { National Financial } \\
\text { Expenditure on } \\
\text { Agriculture (per capita) }\end{array}$ \\
\hline Farmers' Income & $\mathrm{Y}$ & $\begin{array}{l}\text { Per Capita Net Income } \\
\text { of Rural Residents }\end{array}$ \\
\hline
\end{tabular}

\section{B. Data Sources}

This paper analyzes the data of Heilongjiang Province from 1999 to 2014. The data involved are from the Insurance Yearbook of Heilongjiang Province, the Financial Yearbook of Heilongjiang Province, CNKI and so on. In this paper, SPSS19.0 software is used to fill the missing data with the linear trend of the missing data, and the obtained data are accurate and objective.

\section{EMPIRICAL ANALYSIS}

\section{A. Estimation of Rural Financial Service Level in Heilongjiang Province}

1) The Applicability of the Data
As can be seen from Table II, the seven indicators all show a positive correlation, the correlation coefficient is much larger than 0.3 . This shows that there is a strong linear relationship between the indicators, suitable for principal component analysis. Further investigation of the above criteria for $\mathrm{KMO}$ and Bartlett Sphere Test (see Table III). Through the KMO test and Bartlett test results can be clearly concluded that this data is suitable for principal component analysis.

TABLE II. CORRELATION COEFFICIENT MATRIX OF THE ORIGINAL VARIABLE

\begin{tabular}{|c|c|c|c|c|c|c|c|c|}
\hline & & JG & $\mathrm{CY}$ & $\mathrm{CX}$ & DK & $\mathrm{BF}$ & PK & $\mathrm{CZ}$ \\
\hline \multirow[t]{7}{*}{ Related } & JG & 1.000 & 0.482 & 0.423 & 0.355 & 0.421 & 0.410 & 0.394 \\
\hline & $\mathrm{CY}$ & 0.482 & 1.000 & 0.886 & 0.897 & 0.891 & 0.780 & 0.864 \\
\hline & $\mathrm{CX}$ & 0.423 & 0.886 & 1.000 & 0.960 & 0.979 & 0.836 & 0.978 \\
\hline & DK & 0.355 & 0.897 & 0.960 & 1.000 & 0.975 & 0.842 & 0.936 \\
\hline & $\mathrm{BF}$ & 0.421 & 0.891 & 0.979 & 0.975 & 1.000 & 0.903 & 0.970 \\
\hline & PK & 0.410 & 0.780 & 0.836 & 0.842 & 0.903 & 1.000 & 0.821 \\
\hline & $\mathrm{CZ}$ & 0.394 & 0.864 & 0.978 & 0.936 & 0.970 & 0.821 & 1.000 \\
\hline & & \multicolumn{7}{|c|}{ KMO INSPECTION AND BARTLETT INSPECTION } \\
\hline \multicolumn{7}{|c|}{$\begin{array}{l}\text { Samples are sufficient to measure the Kaiser- } \\
\text { Meyer-Olkin metric }\end{array}$} & \multicolumn{2}{|c|}{0.799} \\
\hline \multicolumn{4}{|c|}{ Bartlett's Spherical Test } & \multicolumn{3}{|c|}{$\begin{array}{c}\text { Approximate card side } \\
\text { df } \\
\text { sig }\end{array}$} & \multicolumn{2}{|c|}{$\begin{array}{l}167.133 \\
21 \\
0.000\end{array}$} \\
\hline
\end{tabular}

The main component analysis method of SPSS19.0 analysis software is used to complete the information extraction. The common factor variance table gives the information extracted from each original variable. The loss of the original variable JG original variable More, the other six original variable information loss degree is very small, the main component is very good contains all the original variables of most of information.

\section{2) Principal Component Analysis}

Using SPSS19.0 analysis software, follow the cumulative contribution rate of more than $80 \%$ and the eigenvalue is greater than 1 to determine the principle of selecting a principal component, through Table IV. can be judged by the main component has seven primitive variables of most of the original information, the analysis is better.

TABLE IV. EXPLAINS THE TOTAL VARIANCE

\begin{tabular}{c|cccccc}
\hline \multirow{2}{*}{$\begin{array}{c}\text { Ingre- } \\
\text { dients }\end{array}$} & \multicolumn{3}{|c}{ Initial eigenvalue } & \multicolumn{3}{c}{ Extract squares and load } \\
\cline { 2 - 7 } & total & $\begin{array}{c}\text { Variance } \\
\%\end{array}$ & $\begin{array}{c}\text { Accumulated } \\
\%\end{array}$ & total & Variance\% & $\begin{array}{c}\text { Accumulat- } \\
\text { ed\% }\end{array}$ \\
\hline 1 & 5.730 & 81.853 & 81.853 & 5.730 & 81.853 & 81.853 \\
2 & 0.801 & 11.445 & 93.298 & & & \\
3 & 0.241 & 3.449 & 96.747 & & & \\
4 & 0.152 & 2.177 & 98.925 & & & \\
5 & 0.054 & 0.767 & 99.692 & & & \\
6 & 0.017 & 0.239 & 99.931 & & & \\
7 & 0.005 & 0.069 & 100.000 & & & \\
\hline
\end{tabular}


3) The Level of Rural Financial Services in Heilongjiang Province Over the Years

After the standardization of SPSS19.0 software, the level of rural financial services in Heilongjiang Province from 1999 to 2014 is shown in Table V. It can be seen from the calculation results that the growth trend of rural financial services is obvious, the level of rural financial services in 1999 The score of -0.71991 , then, with the passage of time the level of rural financial services to gradually increase the score in 2014 reached a maximum of 1.92175 .

TABLE V. RURAL FINANCIAL SERVICE LEVEL IN HEILONGJIANG PROVINCE OVER THE YEARS

\begin{tabular}{cccc}
\hline year & score & year & score \\
\hline 1999 & -0.7199 & 2007 & -0.3933 \\
2000 & -0.74557 & 2008 & 0.41223 \\
2001 & -0.76324 & 2009 & 0.42859 \\
2002 & -0.88517 & 2010 & 0.45012 \\
2003 & -0.90529 & 2011 & 0.64014 \\
2004 & -0.89428 & 2012 & 1.16819 \\
2005 & -1.00366 & 2013 & 1.90583 \\
2006 & -0.47375 & 2014 & 1.92175 \\
\hline
\end{tabular}

Significant improvement in the level of rural financial services, thanks to the development of the national financial market environment and the strong support of the three-rural policy.

\section{B. An Empirical Study on the Relationship between Financial Service Level and Farmers' Income}

\section{1) ADF Unit Toot Test}

The per capita net income of rural residents in Heilongjiang Province $\mathrm{Y}$ time series and rural financial service level FW time series using the ADF test method for unit root test. As can be seen from the results in Table VI, the sequence $\mathrm{Y}$ has a unit root and the first order difference of the sequence $\mathrm{Y}$ is stationary at a critical level of $5 \%$. The sequence FW contains the unit root, which is a nonstationary time series. The first order differential sequence of the FW time series has no unit roots and is a stationary sequence, i.e. FW is a first order single time series.

TABLE VI. ADF UNIT RoOT TEST

\begin{tabular}{ccccc}
\hline variable & $\begin{array}{c}\text { ADF } \\
\text { statistic }\end{array}$ & $\begin{array}{l}5 \% \text { critical } \\
\text { value }\end{array}$ & P value & conclusion \\
\hline Y & 4.476 & -3.000 & 1 & unstable \\
D (Y.1) & -3.326 & -3.000 & 0.0138 & stable \\
FW & 0.939 & -3.000 & 0.9936 & unstable \\
D(FW.1) & -3.579 & -3.000 & 0.0062 & stable \\
\hline
\end{tabular}

2) E-G Two-step Cointegration Test

It is found that the first-order differential sequence of rural per capita net income (Y) and rural financial service level (FW) are stable, and there is a possibility of cointegration between them. Therefore, the rural financial service level FW as an explanatory variable, the per capita net income of rural resident's Y is the explanatory variable, using E-G two-step method for co-integration test.

First, the regression model is estimated by OLS method.

$$
Y=2725.848 * F W+4849.098
$$

The measurement results show that the adjusted $\mathrm{R}^{2}$ is 0.9455 , the F statistic is 242.69 , and the probability $\mathrm{P}$ is zero. The Q statistic and the LM statistic test can also prove that the model obtained in this paper has no sequence correlation. The $\mathrm{ADF}$ test is performed on the residual sequence of this equation. The results are as follows:

TABLE VII. RESIDUAL SEQUENCE ADF TEST

\begin{tabular}{ccccc}
\hline variable & $\begin{array}{c}\text { ADF } \\
\text { statistic }\end{array}$ & $\begin{array}{l}5 \% \text { critical } \\
\text { value }\end{array}$ & P value & conclusion \\
\hline Res & -3.547 & -3.000 & 0.0069 & stable \\
\hline
\end{tabular}

It can be seen from Table 3.6 that the residual sequence is a stationary sequence at the $5 \%$ significance level, which can be used to determine the long-term equilibrium cointegration between the per capita net incomes of rural resident's $\mathrm{Y}$ and the rural financial service level FW.

\section{3) The Establishiment of VAR Model}

\section{a) Granger Causality Test}

TABLE VIII. GRANGER CAUSALITY TEST RESULTS

\begin{tabular}{cccll}
\hline original hypothesis & $\begin{array}{c}\text { Optimal- } \\
\text {-lag }\end{array}$ & $\begin{array}{c}\mathrm{F} \\
\text { statistic }\end{array}$ & $\begin{array}{l}\mathrm{P} \\
\text { value }\end{array}$ & result \\
\hline $\begin{array}{c}\text { Y does not granger } \\
\text { cause FW }\end{array}$ & 2 & 4.9651 & 0.084 & Accept \\
$\begin{array}{c}\text { FW does not granger } \\
\text { cause Y }\end{array}$ & 2 & 19.159 & 0.000 & Refuse \\
\hline
\end{tabular}

It can be seen from Table VIII that under the 5\% significance level, the per capita net income of rural residents is not the Granger reason of rural financial service level FW, the level of rural financial service is the per capita net income of rural residents in Heilongjiang Province Cause.

\section{b) Impulse Response}

Based on the VAR model, the impulse response analysis of the rural financial service level FW and the per capita net income of the rural residents can be obtained. As shown in Fig.1

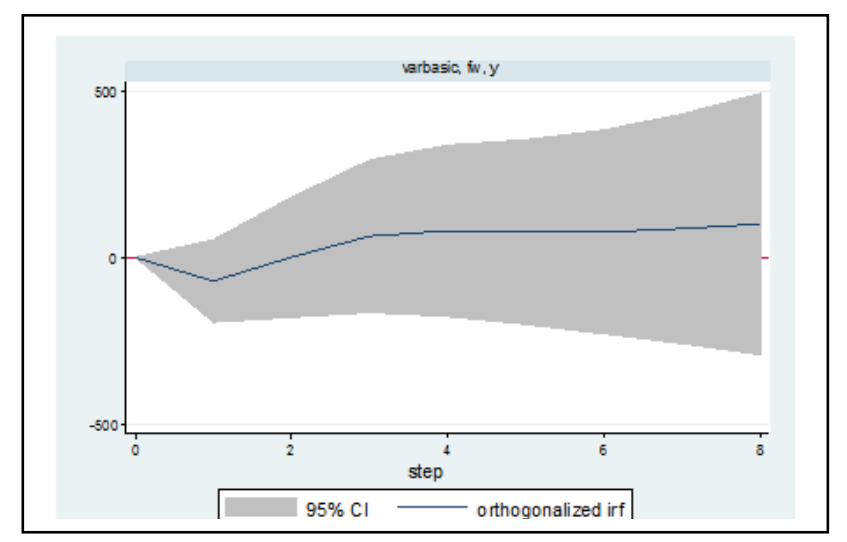

Fig. 1. Impulse response of $\mathrm{Y}$ to $\mathrm{FW}$ 
It can be seen from the overall trend that the level of rural financial services has a sustained and positive impact on the per capita net income of rural residents. Therefore, it can be considered that the impact of rural financial service level $\mathrm{F}$ plays a very positive role in the per capita net income of farmers.

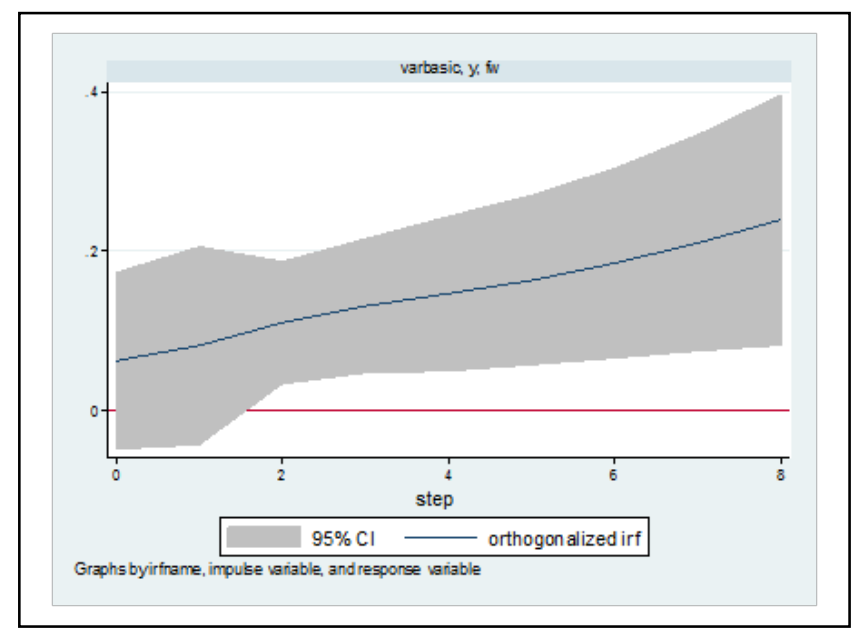

Fig. 2. Impulse response of FW to $\mathrm{Y}$

Fig.2 shows the impulse response of the rural financial service level FW for a standard deviation impact from the per capita net income of farmers. It can be seen from the figure that when the rural residents per capita net income a positive impact, the level of rural financial services immediately showed an upward trend, and this trend is sustained and stable. Therefore, it can be considered that the per capita net income of farmers has played a very positive role in the level of rural financial services.

\section{CONCLUSION}

Based on the empirical analysis of the relationship between rural financial service level and per capita net income of rural residents in Heilongjiang Province from 1999 to 2014, there is a long - term equilibrium relationship between rural financial service level and farmer 's income in Heilongjiang Province. The positive effect of rural financial service level on the per capita net income of rural residents in Heilongjiang Province is more significant. The per capita net income of rural residents in Heilongjiang Province has a positive effect on the level of rural financial services in China.

To better serve the rural, government and rural areas of financial institutions to continuously enhance and improve the financial services provided in rural areas, to promote the increase in farmers' income play an active role. Therefore, this paper proposes the following countermeasures:

\section{A. Establish and Perfect the Rural Financial Service Systen}

Efforts to build a multi-level banking financial institutions, non-banking financial institutions and other micro-finance organizations composed of wide coverage, moderate competition of rural financial service system; implement policy finance, commercial finance and cooperative finance complementary functions, Cooperation, to promote the convenience of rural financial services, availability continued to increase.

\section{B. The formation of government financial support and financial institutions of the common development of credit services}

On the one hand, the government should increase financial investment and improve the rural financial development environment. On the other hand, rural cooperative credit cooperatives as an important rural financial services institution, in the service of rural finance occupy a dominant position. So, the government should increase support for rural cooperative credit cooperatives.

\section{Vigorously build financial facilities in rural areas and increase the number of business outlets and service personnel in financial institutions}

On the one hand, targeted to increase the financial outlets and personnel investment, improve the rural areas of sustainable development of basic financial services supply network, at the same time to organize agricultural assistance to provide a comprehensive service pilot, capital and manpower to achieve effective Configuration; on the other hand actively promote the banking financial institutions, payment agencies and clearing institutions to carry out all-round, multi-level cooperation, so that rural areas of payment and settlement channels more smooth.

\section{Establish and improve the agricultural insurance system}

First, according to the different risk characteristics of agricultural production process, improve the agricultural insurance policy. Second, in the rural areas to establish and improve the policy of insurance-based, including the company system, cooperation and other forms of coexistence of insurance system. Third insurance companies to continue to innovate agricultural insurance products.

\section{REFERENCES}

[1] Huang Zhong,”Study on rural financial ecological environment,"Hunan: Hunan Agricultural University Press, 2014.

[2] Gao Yan,"New Analysis on the Relationship between Financial Development and Economic Growth,”Jiangxi : East China Jiaotong University Press, 2014.

[3] Ji Min, Zhu Hongmei,”National Innovation of Rural Financial Service ,"(in Chinese) China Finance, vol.15,pp38-40,May 2015.

[4] Zhao Jun-ying,"Study on the Development of Low-carbon Agriculture and Innovative Path of Rural Financial Services - Based on Carbon Finance," (in Chinese) Eco-Economy, vol.05,pp68-71,July 2012.

[5] Hatlebakk, Magnus, Capacity-constrained collusive price discrimination in the informal rural credit markets of Nepal. Review of development economics. Feb 2009. Vol12:70-86.

[6] Barslund, Mikke, Trap, Finn. Formal and informal rural credit in four provinces of Vietnam. Journal of development studies. 2008. Vo144: 485-503 